\begin{tabular}{lccr} 
A R C H I V E & O F & M E C H A N I C A L & E N G I N E E R I N G \\
\hline VOL. LXII & 2015 & Number 2
\end{tabular}

10.1515/meceng-2015-0013

Key words: XFEM, composite laminates, fracture processing zone, crack opening displacement

MOHAMMED Y. ABDELLAH ${ }^{*}$, MOHAMMAD S. ALSOUFI ${ }^{* *}$, MOHAMED K.

HASSAN $^{* * *}$, HAMZA A. GHULMAN ${ }^{* *}$, AHMED F. MOHAMED **

\title{
EXTENDED FINITE ELEMENT NUMERICAL ANALYSIS OF SCALE EFFECT IN NOTCHED GLASS FIBER REINFORCED EPOXY COMPOSITE
}

\begin{abstract}
Nominal strength reduction in cross ply laminates of $[0 / 90]_{2 \mathrm{~s}}$ is observed in tensile tests of glass fiber composite laminates having central open hole of diameters varying from 2 to $10 \mathrm{~mm}$. This is well known as the size effect. The extended finite element method (XFEM) is implemented to simulate the fracture process and size effect (scale effect) in the glass fiber reinforced polymer laminates weakened by holes or notches. The analysis shows that XFEM results are in good agreement with the experimental results specifying nominal strength and in good agreement with the analytical results based on the cohesive zone model specifying crack opening displacement and the fracture process zone length.
\end{abstract}

\section{Introduction}

Glass fiber composite laminates have great variety of applications in aerospace industry [1-3]. The computational fracture mechanics has been applied and regarded as suitable tool to predict the fracture and failure of engineering structures of such material [4]. The nominal strength of the composite material is an essential parameter in modeling the mechanical properties of these materials [5]. The size effect has a particular case and more specialties when simulating or modeling the strength of composite material [6-11]. The size effect is defined as the decrease of nominal strength with the increase of composite material specimen size [11] or defect size. Size

* Mechanical Engineering Department, Faculty of Engineering, South Valley University, Qena, Egypt, 83521

** Mechanical Engineering Dept., College of Engineering and Islamic Architecture, Umm Al-Qura University, KSA

*** Production Engineering and design Department, Faculty of Engineering, Minia Universities, Minia, Egypt, 61111 
218 MOHAMMED Y. ABDELLAH, MOHAMMAD S. ALSOUFI, MOHAMED K. HASSAN, HAMZA A. GHULMAN, AHMED F. MOHAMED

effects are observed in composite materials and other quasibrittle materials subjected to various types of mechanical loading [12-24].

The cohesion element with mixed-mode capability has been proposed and demonstrated in reference [25]. This element was used at the interface between solid finite elements to model the initiation and non-self-similar growth of delaminations. The softening function of two parameter power law has been applied for mixed mode conditions. The numerical results were in good agreement with the test results and they indicated that the proposed mixed-mode criteria can predict the strength of composite structures that exhibit progressive delamination.

Yashiro et al. [26] presented the numerical model to predict both the damage process of the laminate and the change in the reflection spectrum from the embedded fiber Bragg Grating (FBG) sensor. This is approach allowed for prediction of multiple damage states in composite laminates. The proposed approach was then applied to explain the results of a quasi-static tensile test for a notched CFRP cross-ply laminate with an implanted FBG sensor. The results show that this approach is valuable tool for predicting multiple damage states in composite laminates.

The cohesive zone finite element approach was developed with two constitutive laws. The first is the linear cohesive traction-crack opining relation, and the other is the exponential softening response. The attainability of the proposed model and the effects and disadvantages of the two material laws are shown by some numerical examples [27].

Aymerich et al. [28] used FE models with interface elements adapting a bilinear cohesive law in order to simulate the impact response of cross-ply graphite/epoxy laminated plates. The results of the proposed model provided correct simulation of the impact response of laminates in a wide range of energy values and predicted successfully size, shape and location of main damage mechanisms. The results of the analysis also pointed out the importance of using the damage criterion capable of accounting for the constraining effect of out-of-plane compression on the initiation of the cohesive zone.

The XFEM has been used for simulation of delamination in GLARE composite [46]. In this study, the double cantilever beam made of fiber metal laminates was considered. The results indicate that XFEM is a suitable technique to simulate failure analysis of such materials.

The novelty of the present paper consists in giving a complete description of new finite element method called XFEM with enrichment functions, suitable for discontinuities, as there are very few papers that use this new method of simulation for fracture mechanics of composite laminates. The XFEM has a great variety of advantages, which will be clearly illustrated in 
this paper. The difference between this advanced fracture mechanics finite element analysis and conventional finite element method will be highlighted.

The paper is organized as follows: firstly, the fundamental enrichment function and crack tip field function of meshless method is outlined; secondly, the linear cohesive law model is presented, and the XFEM domain is built up with specified mesh and boundary conditions; finally the numerical simulation is compared with the experimental results of specimen size effect of glass fiber composite laminates of cross ply stacking sequences $[0 / 90]_{2 \mathrm{~s}}$.

\section{Extended Finite Element Method (XFEM)}

Recently, a new numerical method called the Extended Finite Element Method (X-FEM) has been developed by Belytschko and Black [29]. Based on Melenk and Babuska [30], X-FEM uses the concept of partition of finite element unity and enrichment function. The useful aspect of implementation of X-FEM is that the mesh does not need to conform to the geometry of the problem anymore. Therefore, the analysis of fracture process can be also conducted when the cracks propagate without remeshing and with the numerical accuracy increased around the crack tips.

The enrichments functions are expressed as follows [31]:

$$
u_{x f e m}(X)=\sum_{i \in \Gamma} N_{i}(X) u_{i}+\sum_{i \in J} N_{i}(X) H(X) a_{i}+\sum_{i \in K}\left[N_{i}(X) \sum_{\alpha=1}^{4} F_{\alpha}(X) b_{i \alpha}\right]
$$

where $(\Gamma)$ is the set of all nodes in the mesh, $\left(N_{i}(X)\right)$ is the nodal shape function and $\left(u_{i}\right)$ is the standard (degree of freedom) DOF of node $(i)\left(u_{i}\right.$ represents the physical nodal displacement for non-enriched nodes only). The subsets $(J)$ and $(K)$ contain the nodes enriched with Heaviside Function $(H(X))$ or crack-tip function $\left(F_{\alpha}(X)\right)$, respectively, and $\left(a_{i}, b_{i \alpha}\right)$ are the corresponding DOFs. The first and second term on the right-hand side is applicable to all nodes in the model; the third term is valid for nodes whose shape function support is cut by the crack interior; and the third term is used only for nodes whose shape function support is cut by the crack tip [32]. The Heaviside function $(H(X))$ is defined as follows:

$$
H(X)=\left\{\begin{array}{r}
-1, \text { if } x>0 \\
1, \text { if } x<0
\end{array}\right.
$$

The crack-tip function $\left(F_{\alpha}(X)\right)$ contains the enrichment functions (branch functions) used to increase the accuracy of the numerical solution around crack tip and their formulation depends on the nature of the problem to 
220 MOHAMMED Y. ABDELLAH, MOHAMMAD S. ALSOUFI, MOHAMED K. HASSAN, HAMZA A. GHULMAN, AHMED F. MOHAMED

be solved. For $L E F M$ problems, these functions are chosen based on the asymptotic behavior of the displacement field at the crack tip [29]:

$$
F_{\alpha}(X)=\left[\sqrt{r} \sin \frac{\theta}{2}, \sqrt{r} \cos \frac{\theta}{2}, \sqrt{r} \sin \theta \sin \frac{\theta}{2}, \sqrt{r} \sin \theta \cos \frac{\theta}{2}\right]
$$

Where $(\theta, r)$ is a polar coordinate system with its origin at the crack tip and when $(\theta=0)$ is tangent to the crack at the tip, $\left(\sqrt{r} \sin \frac{\theta}{2}\right)$ takes into account the discontinuity across the crack face. This function has a lot of applications including biomaterial, and elastic-plastic power law hardening material.

\subsection{XFEM domain}

In addition to the asymmetry case, the finite element domain was divided into two regions to reduce calculations time. The domain involves the composite half-plate from cross ply glass fiber laminate composite having a stacking sequence of $[0 / 90]_{2 \mathrm{~s}}$, thickness of $4 \mathrm{~mm}$ and length of $150 \mathrm{~mm}$. The width of theses laminates varies with the hole diameter according to the relation $(d / w=1 / 6)$ (see Fig. 1). The plate domain is created as a solid part of solid section where each ply direction is considered corresponding to each actual ply direction. The X-FEM enrichment domain function with the crack is the hole and input order as follows:

*Enrichment, name $=$ Crack -1, type $=\underline{\text { PROPAGATION CRACK, elset=_PickedSet33 }}$

The solid composites section is used for the X-FEM domain, whereas the thickness section is created as every four ply have one single solid composites section. Therefore, there are two sections of the domain that serve the
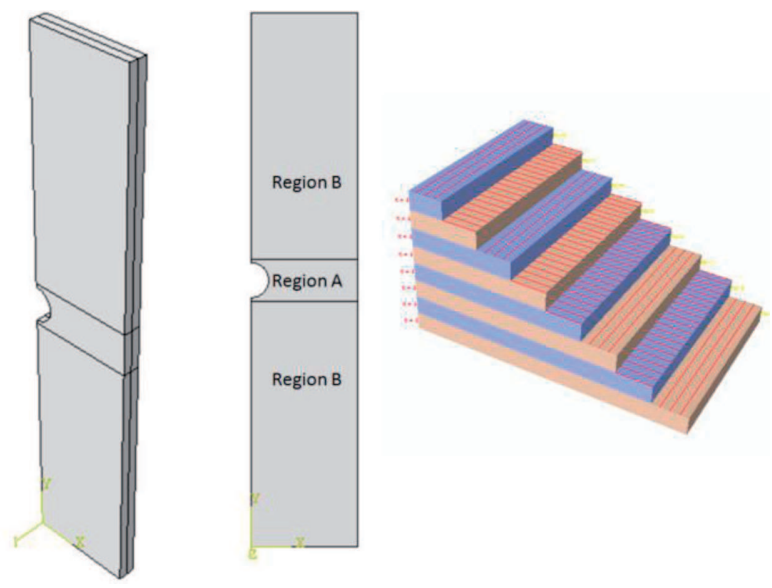

Fig. 1. Domain of the extended finite element method 
$\mathrm{X}$-FEM purpose. The evaluated damage is maximal at crack opening and is calculated using the following equation [45]:

$$
\delta_{n}=\sqrt{\left\langle\delta_{n}\right\rangle^{2}+\delta_{s}^{2}+\delta_{t}^{2}}
$$

The following analysis uses the elastic properties of glass fiber reinforced polymer that are listed in Table 3 . The maximum principal stress is the value of the un-notched nominal strength which is measured as (167.25) MPa. In addition, the damage evaluation criterion is maximum traction displacement (maximum crack opening of the composite specimen is experimentally measured as $0.3 \mathrm{~mm}$ ). Therefore, the input file of the order line in the software becomes as follow:

*Damage Initiation, criterion=MAXPS

167.25.,

*Damage Evolution, type=DISPLACEMENT

0.3 ,

*Damage Stabilization

$1 \mathrm{e}-5$

\subsection{X-FEM domain mesh}

The swept meshing technique is used to generate dense mesh in region A, whereas coarser structure meshing is used for the other domain region, part $\mathrm{B}$, to reduce the calculations time. Moreover, the $(C 3 D 8 R)$ element type is used in the domain. The section through thickness is simulated using two independent sections to help node set convergence.

\subsection{Mesh objectivity and convergence}

The mesh subjectivity of the proposed model is illustrated by simulating the response of a notched GFRP laminate which is loaded in tension and has a tacking sequence of $[0,90]_{2 \mathrm{~s}}$. The simulated specimen has $4 \mathrm{~mm}$ in thickness, $250 \mathrm{~mm}$ in length, and $24 \mathrm{~mm}$ in width, and contains a central circular notch which has a diameter of $4 \mathrm{~mm}$. On the other hand, Table 3 lists the used properties. Two finite element models with different mesh refinements are created using the damage model outlined in the previous sections. Along the fracture plane (region A), model 1 uses element of dimensions of $(30 \times 20 \times 40)$, while model 2 uses element of dimensions $(25 \times 15 \times 30)$. Only one-half of the specimen width is modeled. The details of the mesh in both 
222 MOHAMMED Y. ABDELLAH, MOHAMMAD S. ALSOUFI, MOHAMED K. HASSAN, HAMZA A. GHULMAN, AHMED F. MOHAMED

models are shown in Fig. 2. Figure 3 illustrates the load-displacement relation, which is predicted using the proposed constitutive model. It is indicated that the solution is independent of the mesh density refinement.
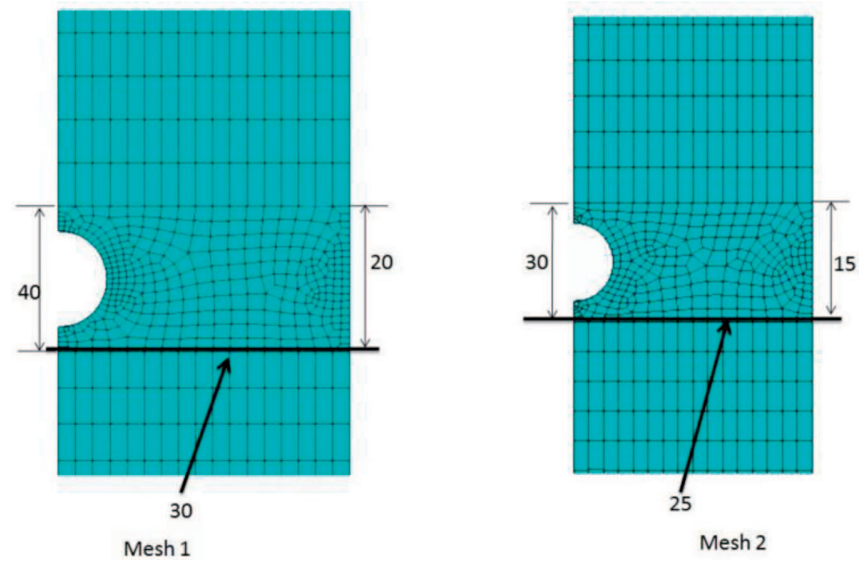

Fig. 2. Different mesh refinements: (a) mesh 1and (b) mesh 2

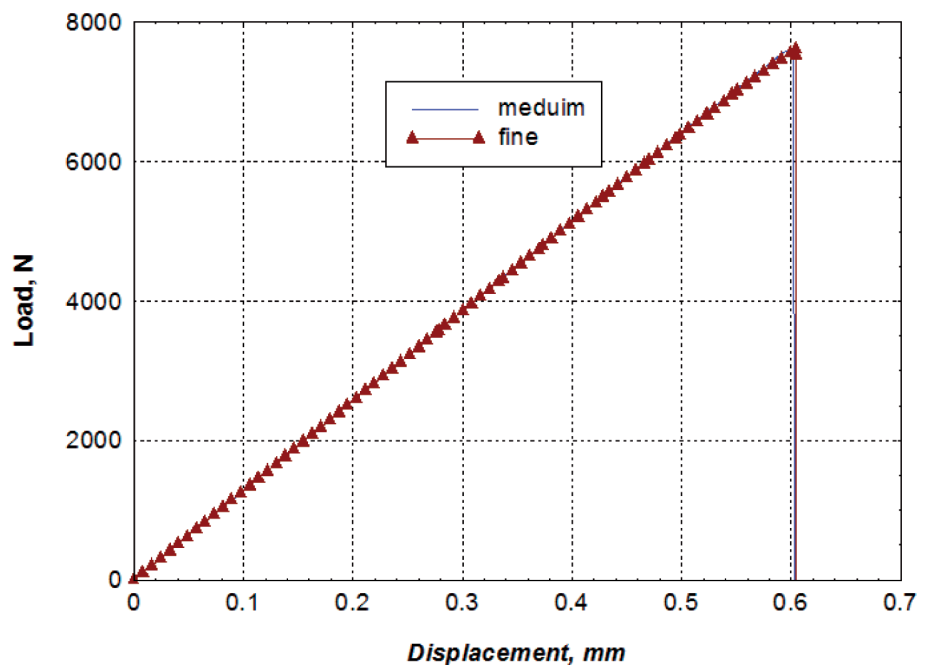

Fig. 3. Load-displacement relation which is predicted by the proposed model

\subsection{Domain boundary conditions}

The domain is constrained to move in the (x) direction while giving a displacement in the (y) direction. Figure 4 shows the domain with boundary condition where asymmetric constrained is given to half of the plate domain at its centerline. 


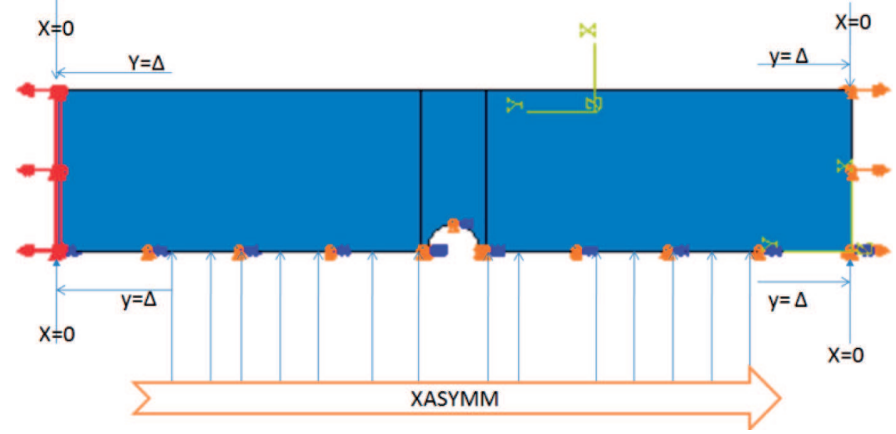

Fig. 4. Boundary conditions of XFEM domain

\subsection{Fracture parameters measurement}

The presence of hole in the composite plate affects the crack opening displacement $\left(W_{n}\right)$. The hole weakens the plate and consequently reduces load-carrying capacity of the plate. The common finite element methods cannot simulate the crack opining displacement which is considered as very important fracture parameter. Common method such as cohesive element finite element method can measure $\left(W_{n}\right)$, but it needs predefined path to simulate the propagation of the crack and needs also special remeshing technique; these lead to time-consuming calculations. Therefore, X-FEM is selected because of its advantages in simulating fracture parameters. Three nodes on the horizontal centerline of the domain are selected to measure the displacement values; $\left(u_{2}\right)$. These nodes are shown in Fig. 5. On the other hand, the fracture process zone length $\left(\ell_{\mathrm{Cr}}\right)$ will be determined from the $\mathrm{X}$-FEM fracture (PHILSM).

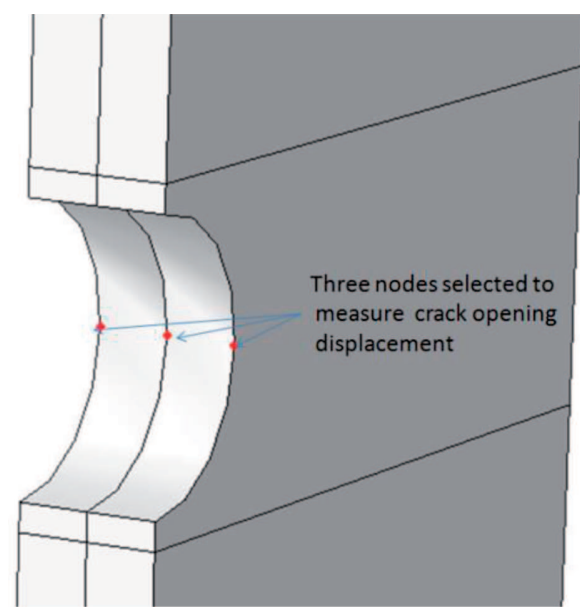

Fig. 5. Nodes location at which COD is measured 
224 MOHAMMED Y. ABDELLAH, MOHAMMAD S. ALSOUFI, MOHAMED K. HASSAN, HAMZA A. GHULMAN, AHMED F. MOHAMED

\section{Experimental and XFEM validation}

\subsection{Experimental work}

The experimental validation is based on the nominal strength of the composite laminates because of all other properties such as crack opening displacement and length of $F P Z$ are based on the nominal strength equation according to each form of the cohesive law.

To validate the model, Glass Fiber Reinforced Epoxy (GFRE) is selected and its constituent characterizations are listed in Tables 1 and 2. The laminates are cross ply of stacking sequences $[0 / 90]_{2 s}$, manufactured by hand

Table 1.

The constituent materials of the composite laminates (CMB international Co.)

\begin{tabular}{|l|l|}
\hline Material & Type \\
\hline Matrix & Resin-Kemapoxy (150RGL) \\
\hline Reinforcement fiber & E-glass (Alkialian)-roving- $p_{l}=2200 \mathrm{gm} / \mathrm{km}$ \\
\hline
\end{tabular}

Table 2.

Mechanical and physical properties of E-glass fiber and epoxy resin, [47,48, 49]

\begin{tabular}{|l|l|l|}
\hline Properties & E-glass & Kemapoxy(150RGL) \\
\hline Density $(\mathrm{kg} / \mathrm{m} 2)$ & 2540 & $1.07 \pm 0.02 \mathrm{~kg} / \mathrm{liters}$ \\
\hline Tensile strength $(\mathrm{MPa})$ & 2000 & $50-100$ \\
\hline Tensile modulus $(\mathrm{GPa})$ & 76 & $1.2-4.5$ \\
\hline Passion ratio & 0.25 & 0.35 \\
\hline In plane shear modulus & 30.8 & 1.24 \\
\hline Failure strain & & 1.7 \\
\hline
\end{tabular}

lay-up techniques [34] and cured for 21 day in room temperature. The fiber volume fraction is about $34 \%$, which is obtained by ignition removal technique according to ASTM D3171-99 standard, [35]. The laminated composite plate has thickness of $4 \mathrm{~mm}$, length of $250 \mathrm{~mm}$ and is cut into specimens of five different hole diameters; $d=2,4,6,8$ and $10 \mathrm{~mm}$, respectively. These diameters are chosen to keep width to diameter ratio $(w / d)$ as 6 [36]. Table 3 lists the elastic properties of unidirectional lamina in the principal material coordinates (1-2) under plane stress which is measured according to ASTM D3039 test standard [37]. The in-plane shear modulus is measured using \pm 45 tensile in-plane shear test method according to ASTM D3518 test standard [38] and is also listed in Table 3. The open hole tension test matrix 
is listed in Table 4. The model needs the value of the fracture energy per unit surface of the laminate composite; therefore it is measured experimentally using compact tension test according to ASTM E399 test standard [39] and the test results are listed in Table 5. Both un-notched nominal strength and the Young's modulus of the laminates are obtained by carrying out a tensile test for five specimens according to ASTM D638M-standard 93 [40] (see Table 5). All tensile tests are performed on universal testing machine (model machine WDW-100) of a load capacity of $200 \mathrm{KN}$, at a controlled speed of $2 \mathrm{~mm} / \mathrm{min}$. The open hole tensile test results are listed in Table 6 and Fig. 5 shows the relation between the remote stress and strain curves for one of this test specimen.

Table 3.

Ply elastic properties

\begin{tabular}{|l|l|}
\hline Property & Mean value \\
\hline Longitudinal young's modulus, $E_{1}(\mathrm{GPa})$ & 27 \\
\hline Transverse young's modulus, $E_{2}(\mathrm{GPa})$ & 5.3 \\
\hline In-plane shear modulus, $G_{12}(\mathrm{GPa}),( \pm 45$ shear test $)$ & 1.24 \\
\hline Major passion ratio, $v_{12}$ & 0.31 \\
\hline Longitudinal strength $\left(X_{t}\right), \mathrm{MPa}$ & 645 \\
\hline Transverse $\left(Y_{t}\right), \mathrm{MPa}$ & 15 \\
\hline
\end{tabular}

Table 4.

Experimental matrix program

\begin{tabular}{|l|l|c|c|}
\hline Diameter & Width & Ratio $w / d$ & Number of specimen used \\
\hline$d_{1}=2$ & 12 & 6 & 5 \\
\hline$d_{2}=4$ & 24 & 6 & 5 \\
\hline$d_{3}=6$ & 36 & 6 & 5 \\
\hline$d_{4}=8$ & 48 & 6 & 5 \\
\hline$d_{5}=10$ & 60 & 6 & 5 \\
\hline
\end{tabular}

The experimental results presented in Table 6 and Fig. 6 identify clearly the specimen size effect: an increase in the hole diameter from 2 to $10 \mathrm{~mm}$ results in an average reduction of $29.5 \%$ in the strength. The size effect is obtained by the development of the fracture process zone, which redistributes the stresses and dissipates energy. 
226 MOHAMMED Y. ABDELLAH, MOHAMMAD S. ALSOUFI, MOHAMED K. HASSAN, HAMZA A. GHULMAN, AHMED F. MOHAMED

Table 5

Un notch specimen fracture properties

\begin{tabular}{|l|c|l|}
\hline Properties & Mean value & STDV \\
\hline Fracture Energy $\left(\mathrm{KJ} / \mathrm{m}^{2}\right)$ & 51.915 & 3.763 \\
\hline Un notch tensile strength, $(\mathrm{MPa})$ & 167.5 & 23.3 \\
\hline Young's modulus, $(\mathrm{GPa})$ & 22.5 & 2 \\
\hline
\end{tabular}

Notch strength of open hole tensile test

\begin{tabular}{|l|c|c|}
\hline Diameter & Mean nominal strength (MPa) & STDV (MPa) \\
\hline 2 & 135 & 4.12 \\
\hline 4 & 121 & 3 \\
\hline 6 & 116.25 & 5.8 \\
\hline 8 & 105 & 3 \\
\hline 10 & 95.5 & 1.11 \\
\hline
\end{tabular}

Table 6.

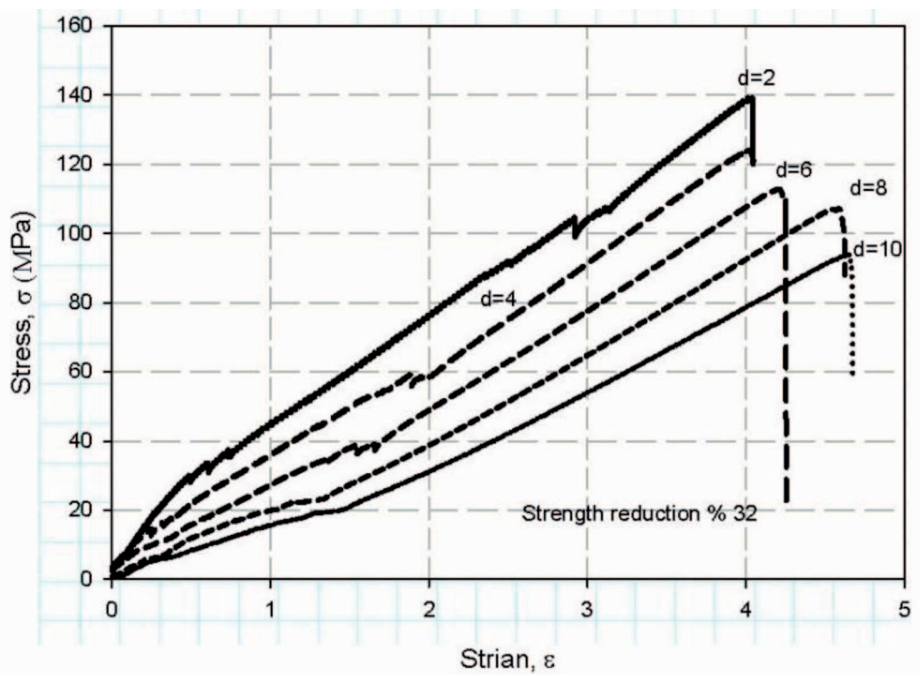

Fig. 6. Stress strain diagram of glass fiber laminate composite showing the size effect [47]

\subsection{Linear cohesive law}

The linear cohesive law which predicts both cracks opening displacement is completely derived in reference [41, 47]. A brief description and extraction will be illustrated as follows:

Figure 7 depicts the linear cohesive law of laminate composite. Failure stress or nominal strength is reached at a certain point on the curve when 
$\left(w_{i}=w_{c}\right)$, that is theoretically at zero cracks face stress. Karihaloo [42] assumed that the nominal strength occurs when the initial crack tip stress becomes zero $\left(w_{i}=w_{c}\right)$, this is just for infinite size specimens. Whereas, the available entire numerical models using cohesive crack show that the stress at the initial crack tip has not yet completely softens to zero. These results were obtained at the peak load and for finite size specimens. Bažant [43] assumed that there is a constant residual stress at the crack face; this stress can be calculated as:

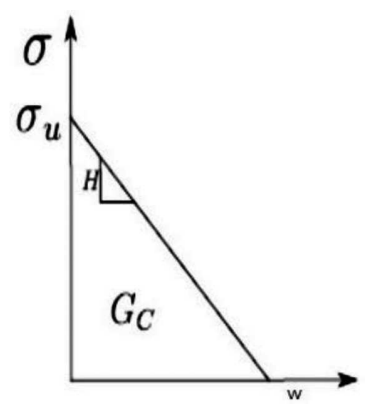

Fig. 7. Form of the linear cohesive law $[41,51]$

$$
\sigma_{\text {Zero }}=\sigma_{\text {un }} \times K_{t}
$$

where this value is nearly equal to the elastic limit or below, the $\left(K_{t}\right)$ is the stress concentration factor for laminates composite around the hole extracted previously [41] and is shown in Fig. 8. This factor is also very important to keep the size effect curve below the plastic limit for infinite width plate $\left(\beta_{w}\right)$. According to Bažant [44], this factor makes also the nominal strength to coincide with the plastic limit or the maximum tensile strength. The transformation function can be obtained by substituting Eq. 7 into Eq. 6. This function connects the nominal strength with the size effect $\left(\rho_{C r}\right)$ of the dimensionless specimen as follows:

$$
\begin{gathered}
w_{i}=\frac{R}{E} f_{i j} \sigma_{i}\left(w_{j}\right) \\
\rho_{C r}=\left\{\begin{array}{l}
0 \rightarrow \text { notch ductile } \\
\infty \rightarrow \text { notch brittle }
\end{array}\right. \\
\bar{\rho}_{C r}=\left(f_{i j}\left(\theta_{\ell}, \beta_{w}\right) \times K_{t}\right)
\end{gathered}
$$


228 MOHAMMED Y. ABDELLAH, MOHAMMAD S. ALSOUFI, MOHAMED K. HASSAN, HAMZA A. GHULMAN, AHMED F. MOHAMED

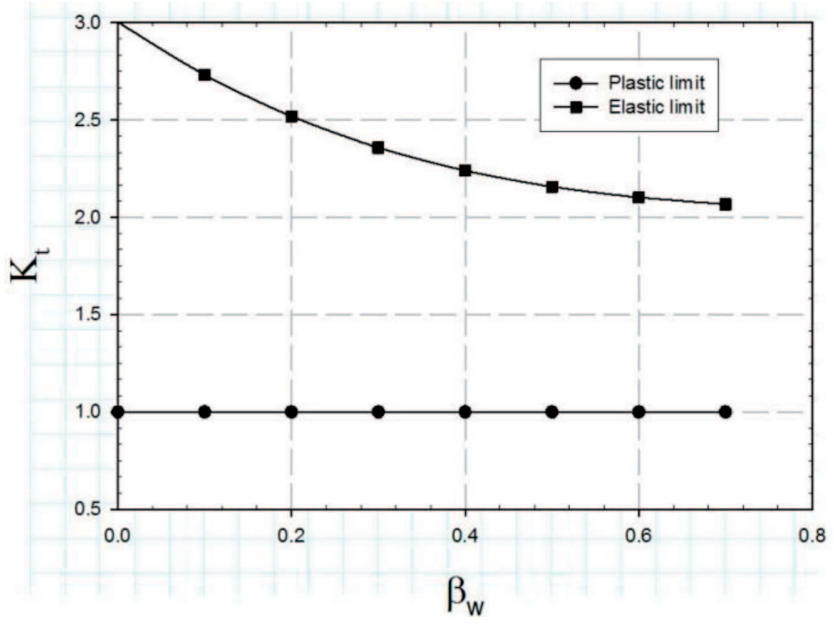

Fig. 8. Stress concentration factor around the hole of the laminate composite [47]

This value is the value at a point just below the critical crack opening ( $w_{i} \leq$ $w_{C}$ ), where failure occurs at maximum (FPZ), which is defined as:

$$
\frac{\partial S_{n}}{\partial \theta_{\ell}}=0
$$

The crack opening profile at failure load is also an important parameter, which should be considered and calculated. As mentioned previously, it is below $\left(w_{C}\right)$. Thus, taking into account Eqn.6 with the cohesive stress, one can calculate as follows:

$$
\bar{w}\left(\bar{x}, \rho_{C r}, \beta_{w}\right)=\frac{w_{i}}{w_{C}}=f_{i j}\left(\theta_{\ell}, \beta_{w}\right) \times \bar{\sigma}_{j}\left(\bar{w}_{j}\right) \times \rho_{C r}
$$

This is the equation of the crack opening and it is related to the stress by the operator function $\left(f_{i j}\right)$ (see reference [41]). The normalized cohesive law is $\left(\bar{\sigma}_{j}\left(\bar{w}_{j}\right)\right)$ where $\left(\bar{\sigma}_{j}\left(\bar{w}_{j}\right)=\left.\sigma_{j}\right|_{\sigma_{u n}}\right)$ and

$$
\begin{gathered}
\beta_{w}=\frac{R}{w} \\
\rho_{C r}=\frac{R}{\ell_{\mathrm{Cr}}} \longrightarrow \ell_{\mathrm{Cr}}=\frac{E G_{C}}{\sigma_{u n}^{2}}, \theta_{\ell}=\frac{R}{\ell_{\mathrm{FPZ}}}
\end{gathered}
$$

Where $\left(\beta_{w}, \rho_{\mathrm{Cr}}\right)$ are aspect ratio and relative specimen size respectively. $\left(\ell_{\mathrm{Cr}}\right)$ is Irwin's characteristic $(w)$ specimen width, $(R)$ hole radius, $\left(G_{C}\right)$ fracture toughness, $\left(\sigma_{u n}\right)$ un-notched strength, $\left(S_{n}\right)$ is nominal strength and $(E)$ Young's modulus of laminate. 


\section{Results and discussion}

The stress component along the $y$-direction $\left(\sigma_{y}\right)$, and the in-plane displacement $\left(u_{y}\right)$ are considered as main important data which can be simulated. Moreover, these fracture parameters are numerically incorporated in ABAQUS/Standard.

Figure 9 shows a comparison between experimental results, which were previously discussed, to validate the obtained XFEM simulations. The experimental data, which will be used in Fig. 6 , are listed in Table 6 for cross ply glass fiber reinforced polymer of the stacking sequence of $[0 / 90]_{2 s}$. It is clear that the proposed simulation results are in good agreement with the experimental data for nominal strength of the laminate composites. The comparison data are listed in Table 7.

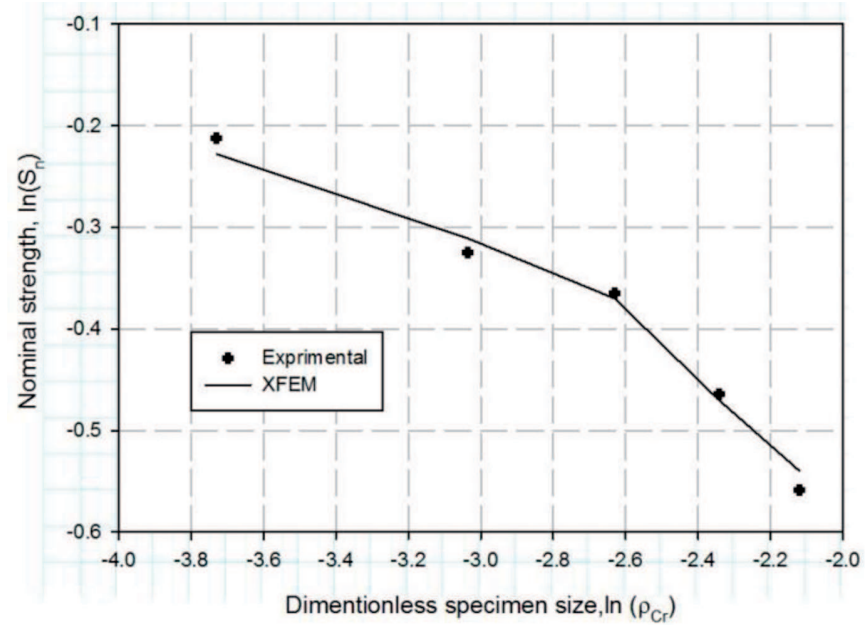

Fig. 9. XFEM validation with experimental nominal strength values of the laminate composites

Table 7

Simulation validations based on nominal strength

\begin{tabular}{|c|c|c|c|}
\hline Diameter $(\mathrm{mm})$ & $\begin{array}{c}\text { prediction strength }(\mathrm{MPa}) \\
\text { XFEM }\end{array}$ & $\begin{array}{c}\text { Experimental } \\
\text { strength (MPa) }\end{array}$ & Error \% \\
\hline$d_{2}$ & 133.3457 & 135 & 1.4 \\
\hline$d_{4}$ & 122.6722 & 121 & .82 \\
\hline$d_{6}$ & 115.6067 & 116.25 & .86 \\
\hline$d_{8}$ & 104.6183 & 105 & .95 \\
\hline$d_{10}$ & 101.585 & 95.5 & 6 \\
\hline Avenge accuracy, $\%$ & 97.5 & \multicolumn{2}{|c}{} \\
\cline { 1 - 3 } & & &
\end{tabular}


230 MOHAMMED Y. ABDELLAH, MOHAMMAD S. ALSOUFI, MOHAMED K. HASSAN, HAMZA A. GHULMAN, AHMED F. MOHAMED

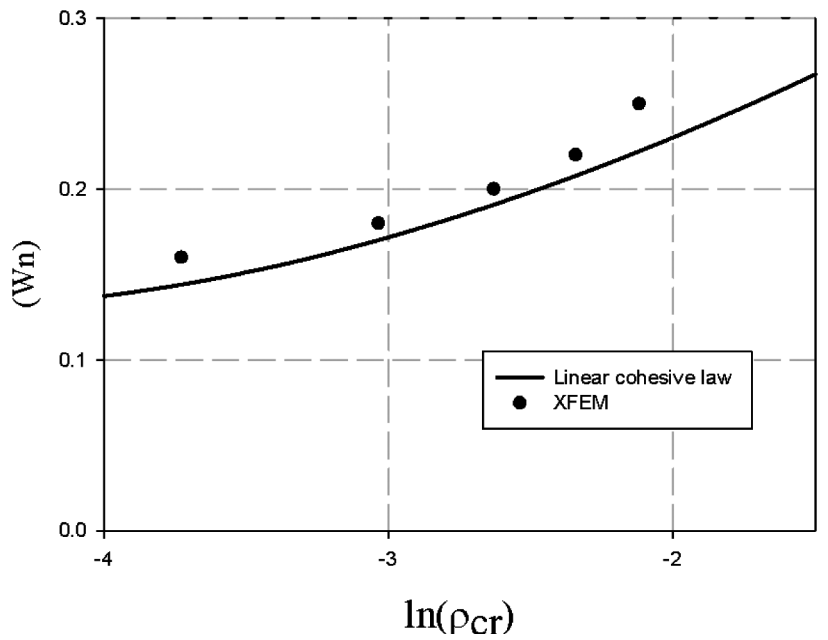

Fig. 10. XFEM validation with linear cohesive law in case of COD results

Table 8 .

Simulation validations based on (COD)

\begin{tabular}{|c|c|c|c|}
\hline \multirow{2}{*}{ Diameter (mm) } & $\begin{array}{c}\text { prediction COD (\% mm) } \\
w_{n}=w_{\text {failure }} / w_{C}\end{array}$ & \multirow{2}{*}{$\begin{array}{l}\mathrm{X}-\mathrm{FEM}(\% \mathrm{~mm}) \\
w_{n}=w_{\text {failure }} / w_{C}\end{array}$} & Error \% \\
\hline & linear & & linear \\
\hline$d_{2}$ & 14.8 & 16 & 7.5 \\
\hline$d_{4}$ & 17.5 & 18 & 2.7 \\
\hline$d_{6}$ & 19 & 20 & 5 \\
\hline$d_{8}$ & 20.7 & 22 & 5.9 \\
\hline$d_{10}$ & 22 & 25 & 12 \\
\hline Avenge accuracy, $\%$ & 93.5 & & \\
\hline
\end{tabular}

Figure 10 and Table 8 show the relation between crack opening displacement and the size effect $\left(\rho_{C r}\right)$ of the dimensionless specimen compared with that obtained by linear cohesive law model (Eq.10). It is clearly shown that the finite element analysis is in good agreement with the linear cohesive law model. The FPZ and the size curve are simulated very well and this is clearly shown in both Fig. 12 and Tables 9. It is observed that the linear cohesive law is very accurate; this is due to the fact that this type of traction separation law is the same as that used in the X-FEM. This law has a great role in simulating the natural case of the stress at the crack face for laminate composites. The failure stress over the two crack faces is piecewise constant, and is decreasing as the crack opening increases. Figure 11 shows the PHILSM contour of the glass fiber laminate composites with holes and stacking sequences of $[0 / 90]_{2 \mathrm{~s}}$. It shows also the location of the signed distance function $(\Phi)$ which is used 

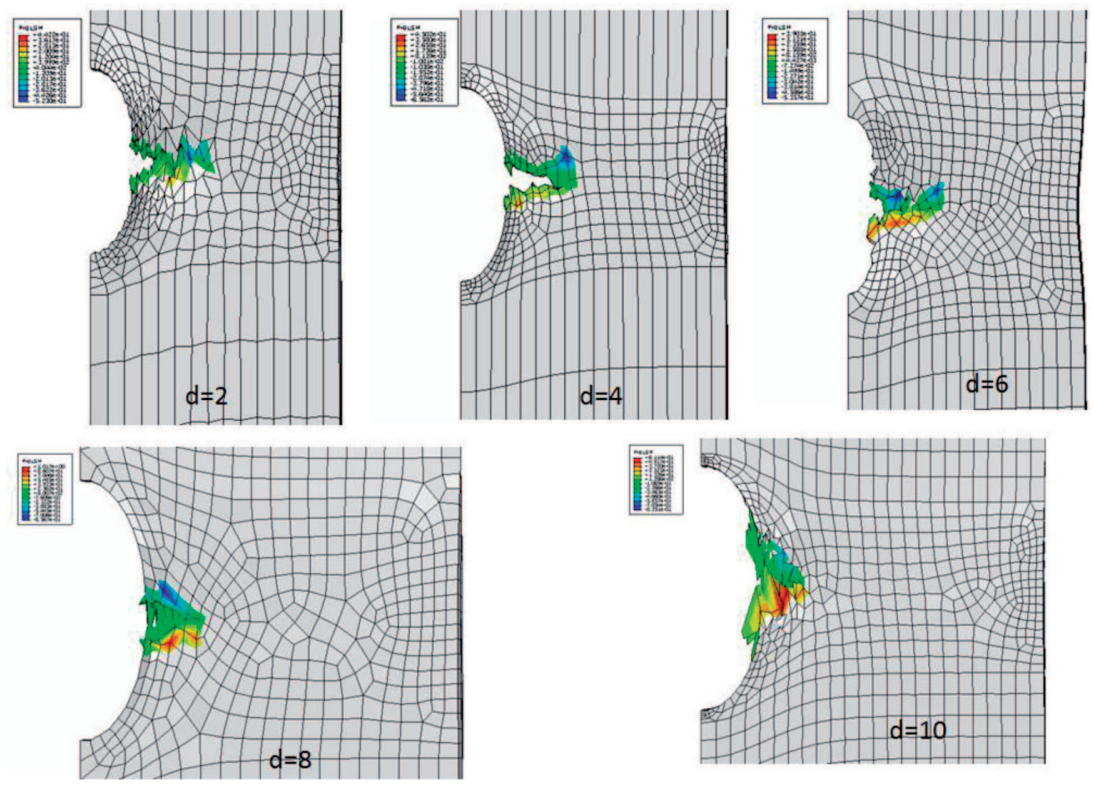

Fig. 11. Contours of PHILSM of the XFEM technique

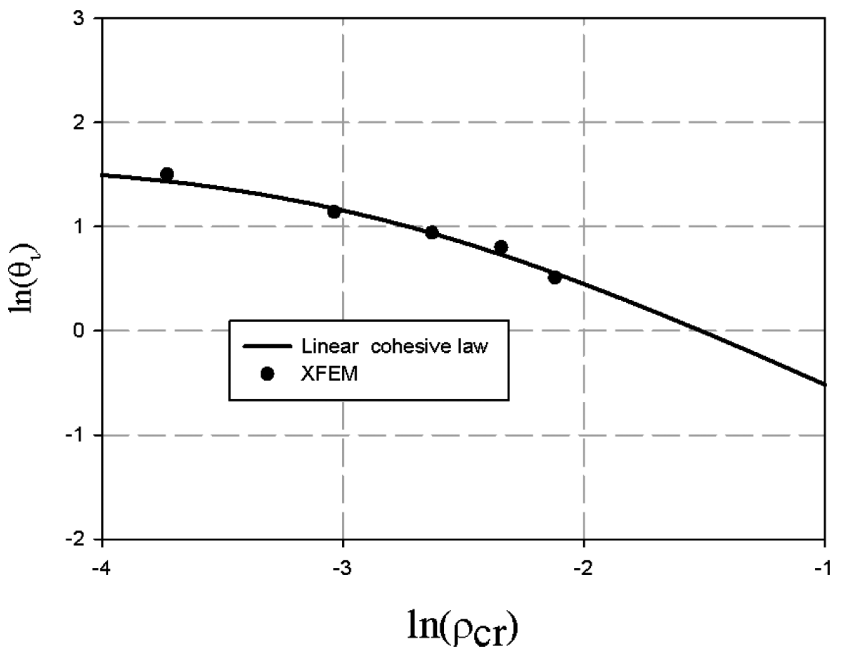

Fig. 12. XFEM validation with linear cohesive law for results of the FPZ length

to represent crack surface. Figure 13 shows STATUSXFEM function which indicates the status of the element with a value between ( 0 and 1$)$. It is clearly visible that the crack opening increases as specimen size increases, while the length decreases; this is in accordance with the linear cohesive law results. Figure14 illustrates the relation between crack opening displacement and load-carrying capacity or nominal strength of the composite laminates. This 
232 MOHAMMED Y. ABDELLAH, MOHAMMAD S. ALSOUFI, MOHAMED K. HASSAN, HAMZA A. GHULMAN, AHMED F. MOHAMED

Table 9.

Simulation validations based on FPZ length

\begin{tabular}{|c|c|c|c|}
\hline \multirow{2}{*}{ Diameter $(\mathrm{mm})$} & $\begin{array}{c}\text { prediction FPZ }(\% \mathrm{~mm}) \\
\theta_{\ell}=\ell_{F P Z} / R\end{array}$ & $\begin{array}{c}\text { X-FEM }(\% \mathrm{~mm}) \\
\theta_{\ell}=\ell_{F P Z} / R\end{array}$ & Error $\%$ \\
\cline { 2 - 4 } & linear & 150 & linear \\
\hline$d_{2}$ & 143 & 114 & 4.6 \\
\hline$d_{4}$ & 117 & 94 & 2.6 \\
\hline$d_{6}$ & 95 & 80 & 1 \\
\hline$d_{8}$ & 74 & 51 & 7.5 \\
\hline$d_{10}$ & 54 & \multicolumn{2}{|}{} \\
\hline Avenge accuracy, $\%$ & 95.7 & &
\end{tabular}

curve doesn't seem to be smooth due to the effect of the node motion through the crack. When simulating the fracture behavior of these composites, the fiber bridging effect is usually encountered. Figure 11 illustrates the surface of fracture, which includes tops and bottoms showing real simulation of the fracture surfaces of these laminate composites.

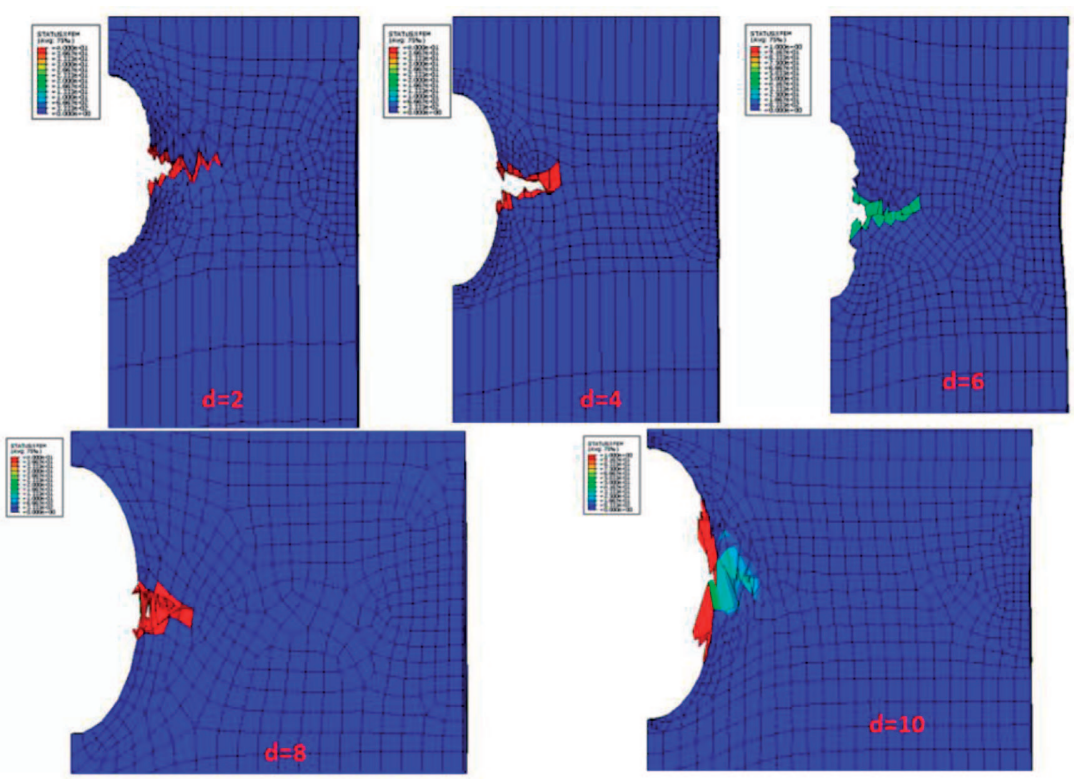

Fig. 13. STATUS of the XFEM 


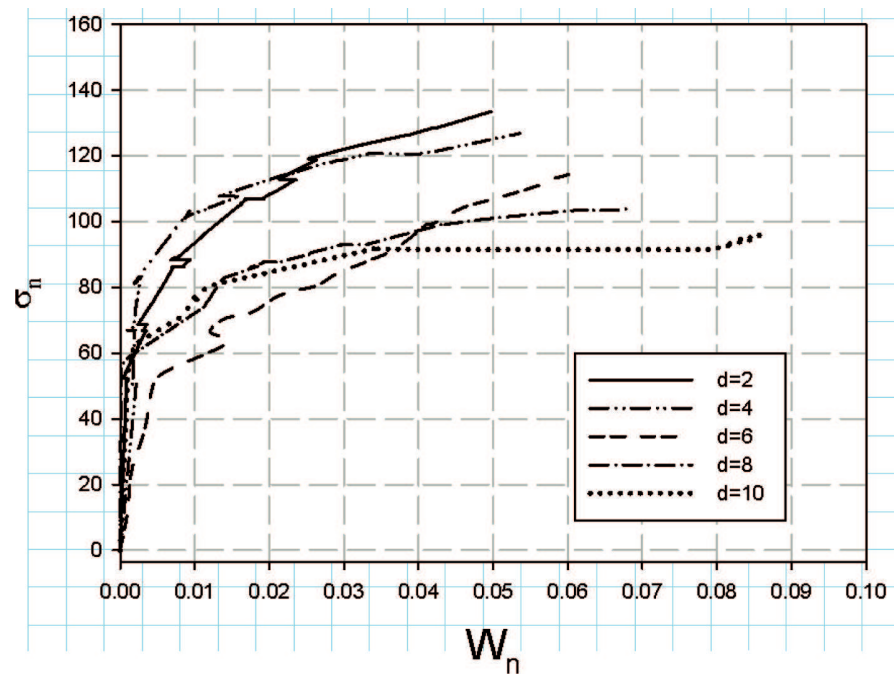

Fig. 14. R-Curve based on COD which is calculated by XFEM technique

\section{Conclusion}

The presented work provides a numerical evaluation of the fracture properties and the size effect aiming at improving fracture analysis, which would be useful when designing and manufacturing laminate composite structures. From this analysis of fracture properties, one can conclude that:

1. XFEM is demonstrated to be a very capable technique to predict the fracture action during the crack propagation to failure of laminate composites. XFEM predicts not only about $97 \%$ of both initiation and propagation energy release rate, but also the fracture history in the laminates, which appear by FEM contours.

2. X-FEM is proved to be a good numerical technique which can simulate, with high precision, the most important fracture parameters of laminate composite. These parameters include crack opening displacement measurements and/or the length of the fracture processing zone (FPZ).

Manuscript received by Editorial Board, August 08, 2014; final version, April 09, 2015.

\section{REFERENCES}

[1] Tsao C.C.: Thrust Force and Delamination of Core Saw Drill During Drilling of Carbon Fiber Reinforced Plastics (CFRP), International Journal of Advanced Manufacturing Technology, Vol. 37, 2008, pp. 23-28.

[2] Krishnamoorthy A., Boopathy S.R., Palanikumar K.: Delamination Analysis in Drilling of CFRP Composites Using Response Surface Methodology, Journal of Composite Materials, Vol. 43, No. 24, 2009, pp. 2885-2901. 
234 MOHAMMED Y. ABDELLAH, MOHAMMAD S. ALSOUFI, MOHAMED K. HASSAN, HAMZA A. GHULMAN, AHMED F. MOHAMED

[3] Vaddadi, Pavankiran, Toshio Nakamura, Raman P. Singh: Transient hygrothermal stresses in fiber reinforced composites: a heterogeneous characterization approach, Composites Part A: Applied Science and Manufacturing 34.8 (2003): 719-730.

[4] Hinton M.J., Soden P.D.: Predicting failure in composite laminates: the background to the exercise, Compos SciTechnol 1998; 58: 1001-10.

[5] Camanho P.P., Maimi P., Davila C.G.: Prediction of size effects in notched laminates using continuum damage mechanics, composite science and technology Vol. 67, pp. 2715-2727, 2007.

[6] Green B.G., Wisnom M.R., Hallet S.R.: An experimental investigation into the tensile strength scaling of notched composites, Composites-Part A 2007; 38: 867-78.

[7] Bazânt Z.P., Daniel I.M., Li Z.: Size effect and fracture characteristics of composite laminates, J Eng Mater Technol 1996; 118: 317-23.

[8] Dvorak G.J., Suvorov A.P.: Size effect in fracture of unidirectional composite plates, Int J Fract 1999; 95: 89-101.

[9] Bazânt Z.P., Zhou Y., Novak D., Daniel I.M.: Size effect on flexural strength of fiber-composite laminates, J Eng Mater Technol 2004; 126: 29-37.

[10] Bazant Z.P.: Size effect, Int J Solids Struct 2000; 37: 69-80.

[11] Wisnom M.R.: Size effects in the testing of fibre-reinforced composites, Compos SciTechnol 1999; 59: 1937-57.

[12] Wisnom M.R., Khan B., Hallet S.R.: Size effects in unnotched tensile strength of unidirectional and quasi-isotropic carbon/epoxy composites, Composite Structures. 2008; 84:21-28.

[13] Bullock R.E.: Strength ratios of composite materials in flexure and in tension, J Compos Mater. 1974; 8:200-6.

[14] Hitchon J.W., Phillips D.C.: The effect of specimen size on the strength of CFRP, Composites. 1978; 9:119-24.

[15] Jackson K.E., Kellas S.: Effect of specimen size on the tensile strength of geometrically scaled [ $+\theta n /-\theta n / 902 n]$ S composite laminates, In: US Army Symposium on Solid Mechanics, Plymouth MA, August 1993.

[16] Wisnom M.R., Atkinson J.A.: Reduction in tensile and flexural strength of unidirectional glass fiber-epoxy with increasing specimen size, Compos Struct.1997; 38: 405-12.

[17] Jackson K.E., Kellas S., Morton J.: Scale effects in the response and failure of fiber reinforced composite laminates loaded in tension and in flexure, Journal of composite materials 26.18 (1992): 2674-2705.

[18] Cunningham M.E., Schoulz S.V., Toth J.M.: Effect of the end tab design on tension specimen stress concentrations, In: Recent advances in composites in the United States and Japan, ASTM STP 864. 1985; p.p. 263-62.

[19] Hojo M., Sawada Y., Miyairi H.: Influence of clamping method on tensile properties of unidirectional CFRP in $0^{\circ}$ and $90^{\circ}$ directions round robin activity for international standardization in Japan, Composites. 1994; 25:786-96.

[20] Wisnom M.R., Maheri M.R.: Tensile strength of unidirectional carbon fibre-epoxy from tapered specimens. In: Second European conference on composites testing and standardization, Hamburg, 1994. p.p. 239-47.

[21] Bing Q., Sun C.T.: Specimen size effect in off-axis compression tests of fiber composites, Composites Part B: Engineering. 2008; 39:20-26.

[22] Soutis C., Lee J.: Scaling effects in notched carbon fibre/epoxy composites loaded in compression, Journal of Materials Science. 2008; 43(20): 6593-98.

[23] Lee J., Soutis C.: Measuring the notched compressive strength of composite laminates: Specimen size effects, Composites Science and Technology. 2008; 68(12): 2359-66.

[24] Wisnom M.R., Hallet S.R., Soutis C.: Scaling Effects in Notched Composites, Journal of Composite Materials. 2010; 44(2): 195-210. 
[25] Camanho P.P., Davila C.G.: Mixed-mode decohesion finite elements for the simulation of delamination in composite materials, NASA-Technical Paper 211737.1 (2002): 33.

[26] Elder D.J., Thomson R.S., Nguyen M.Q., Scott M.L.: Review of delamination predictive methods for low speed impact of composite laminates. Composite Structures, 66(1), 2004, 677-683.

[27] Balzani C., Wagner W.: An interface element for the simulation of delamination in unidirectional fiber-reinforced composite laminates, Engineering Fracture Mechanics 75.9 (2008): 2597-2615.

[28] Aymerich F., Dore F., Priolo P.: Prediction of impact-induced delamination in cross-ply composite laminates using cohesive interface elements, Composites Science and Technology 68.12 (2008): 2383-2390.

[29] Belytschko T., Black T.: Elastic crack growth in finite elements with minimal remeshing, Int. J. Numer Meth Engng, 45(5):601; 20, 1999.

[30] Melenk J.M., Babuska I.: The partition of unity finite element method: Basic theory and applications, Comput Meth App MechsEngrg 1996; 289-314.

[31] Moës N., Dolbow J., Belytschko T.: A finite element method for crack growth without remeshing, International Journal for Numerical Methods in Engineering, Vol. 46, No. 1, 1999, pp. 132-150.

[32] Qian, Zhen-dong, Jing Hu.: Fracture properties of epoxy asphalt mixture based on extended finite element method, Journal of Central South University 19.11 (2012): 3335.

[33] Sukumar N., Moës N., Moran B., Belytschko T.: Extended finite element method for threedimensional crack modeling, International Journal for Numerical Methods in Engineering, Vol. 48, No. 11, 2000, pp. 1549-1570.

[34] Khashaba U.A.: In-plane shear properties of cross-ply composite laminates with different off-axis angles, Composite structures 65.2 (2004): 167-177.

[35] Standard test method constituent of composite material, ASTM D 3171-99, American Society for Testing and Materials (ASTM).

[36] Davis J.R.: Tensile testing, ASM International (OH), (2004).

[37] Standard test method for tensile properties of polymer matrix composite materials, ASTM D 3039/D 3039M-00. West Conshohocken (PA), USA: American Society for Testing and Materials (ASTM).

[38] ASTM D3518. "Standard Test Method for In-Plane Shear Response of Polymer Matrix Composite Materials by Tensile Test of $\mathrm{a} \pm 45^{\circ}$ Laminate." W. Conshohocken, PA: Am. Soc. Test. Mater., (2001).

[39] Standard Method of Test for Plane Strain Fracture Toughness in Metallic Materials, ASTM E399-81, American Society for Testing and Materials, Philadelphia (1981).

[40] Standard ASTM "D638M-93, 1993, "Standard Test Method for Tensile Properties of Plastics (Metric)," Annual Book of ASTM Standards, Part 8: 59-67.

[41] Mohamed K. Hassan, Mohammed Y., Salem T.M., Hashem A.M.: Prediction of nominal strength of composite structure open hole specimen through cohesive laws, international journal of mechanical \& mechanical Engineering IJMME-IJENS Vol. 12, pp. 1-9. http://www.ijens.org/IJMME\%20Vol\%2012\%20Issue\%2001.html

[42] Planas J., Bažant Z.P., Jirasek M.: Reinterpretation of Karihaloo's, size effect analysis for notched quasibrittle structures, international journal of fracture 111: 17-28, 2001.

[43] Goangseup Zi., Bažant Z.P.: Eigenvalue method for computing size effect of cohesive cracks with residual stress, with application to kink-bands in composites, international journal of engineering science Vol. 41, pp. 1519-1534, 2003.

[44] Bažant Z.P., Fellow, ASCE, Z. Li: Zero brittleness size effect method for one size fracture test of concrete, journal of engineering mechanics, pp. 458-468, 1996.

[45] ABAQUS, Abaqus Version. "6.9 Documentation." Providence, RI: DassaultSystemesSimulia Corporation (2009) 
236 MOHAMMED Y. ABDELLAH, MOHAMMAD S. ALSOUFI, MOHAMED K. HASSAN, HAMZA A. GHULMAN, AHMED F. MOHAMED

[46] Curiel Sosa J.L., Karapurath N.: Delamination modelling of GLARE using the extended finite element method.Composites Science and Technology 72.7 (2012): 788-791.

[47] Mohammed Y., Hassan M.K., Abu El-Ainin H., \& Hashem A.M.: Size effect analysis of open-hole glass fiber composite laminate using two-parameter cohesive laws. Acta Mechanica, Volume 226, Issue 4, pp 1027-1044. http://link.springer.com/article/10.1007\%2Fs00707-014-1150-0

[48] Jones R.M.: Mechanics of Composite Materials. Taylor \& Francis, London (1999).

[49] Mallick P.K.: Fiber-Reinforced Composites, 2nd edn. Marcel Dekker Press, New York (1993).

[50] Gibson R.F.: Principles of Composite Material Mechanics. CRC Press, Boca Raton (2011).

[51] Maimi P., Trias D., Gonzalez E.V., Renart J.: Nominal strength of Quasibrittle open hole specimens. Compos. Sci. Technol. 72, 1203-1208 (2012).

\section{Rozszerzona analiza numeryczna metodą elementów skończonych efektu skali w epoksydowym kompozycie $\mathrm{z}$ karbem wzmocnionym włóknem szklanym}

Streszczenie

Zmniejszenie nominalnej wytrzymałości laminatu warstwowego z poprzecznym ułożeniem włókien typu $[0 / 90]_{2 s}$ jest obserwowane dla naprężeń rozciągających w laminatach kompozytowych z włóknem szklanym mających centralny otwór o średnicy od 2 do $10 \mathrm{~mm}$. Jest to dobrze znany efekt rozmiaru (efekt skali). Rozszerzona analiza metodą elementów skończonych (XFEM) została zastosowana w celu symulacji procesu pękania i efektu skali w polimerowych laminatach z włóknem szklanym osłabionych obecnością karbu lub otworu. W pracy wykazano, że wyniki metody XFEM dotyczące wytrzymałości nominalnej są zgodne z danymi eksperymentalnymi, dobrze zgadzają się z wynikami analitycznymi opartymi na modelu strefy spójnej i pozwalają określić przemieszczenie otworu szczeliny i długość strefy procesu pęknięcia. 